\title{
Physicochemical evaluation of field pea (Pisum sativum L.) landraces under rainfed conditions of $\mathrm{AJ} \& \mathrm{~K}$-Pakistan
}

Saba Bashir ${ }^{1}$, Syed Zulfiqar Ali Shah ${ }^{1}$, Raja Mohib Muazzam Naz ${ }^{1 *}$, Abdul Hamid ${ }^{1}$, Salma Anjum ${ }^{1}$, Noosheen Zahid ${ }^{1}$, Mehdi Maqbool ${ }^{1}$, Muhammad Ilyas Khan ${ }^{2}$, Abid Yaqoob ${ }^{1}$, Zahid Hussain Khan ${ }^{1}$ and Aneela Afzal ${ }^{3}$

1. Department of Horticulture, Faculty of Agriculture, University of the Poonch, Rawalakot, Azad Jammu \& Kashmir-Pakistan

2. Department of Plant Breeding and Molecular Genetics, Faculty of Agriculture, University of the Poonch,

Rawalakot, Azad Jammu \& Kashmir-Pakistan

3. Department of Sociology, PMAS-Arid Agriculture University Rawalpindi, Pakistan

*Corresponding author's email: mohibhortian@gmail.com

Citation

Saba Bashir, Syed Zulfiqar Ali Shah, Raja Mohib Muazzam Naz, Abdul Hamid, Salma Anjum, Noosheen Zahid, Mehdi Maqbool, Muhammad Ilyas Khan, Abid Yaqoob, Zahid Hussain Khan and Aneela Afzal. Physicochemical evaluation of field pea (Pisum sativum L.) landraces under rainfed conditions of AJ\&K-Pakistan. Pure and Applied Biology. Vol. 8, Issue 2, pp1033-1042. http://dx.doi.org/10.19045/bspab.2019.80044

\begin{tabular}{llll}
\hline \hline Received: 28/12/2018 & Revised: 16/03/2019 & Accepted: 28/03/2019 & Online First: 04/04/2019 \\
\hline \hline
\end{tabular}

\section{Abstract}

We investigated the physicochemical attributes of nine pea landraces collected from mountainous areas of Azad Jammu and Kashmir-Pakistan using one cultivar (Meteor) as control. Landraces were grown under the same agro-climatic conditions to remove variance caused by environment $\times$ genotype association. There was high physicochemical diversity among the landraces in the content of plant height (23.4-44.7cm), branches per plant(7.55-9.05), flowers/ plant(2-5.32), leaves per plant (31.53-32.80), seeds per pod (3.13-6.83), pods per plant (10.2-6.67), seed weight (g/100 seed) (22.80-23.93), pod length (4.50-8.16cm), total seed yield (10.30-9.99 kg/ha), $\mathrm{pH}(5.0-7.8)$, total protein content (10.76-20.23\%), fiber content (0.76-7.20\%), fat content(1.12-2.86\%), carbohydrates $(79.1-94.38 \mathrm{mg} / \mathrm{g})$ and antioxidant activity (3.83-4.63\%).Together, our results regarding the morphological and nutritional status of existing pea landraces will contribute and increase our knowledge about the field pea and broaden the gene pool available for future plant breeding programs.

Keywords: Field pea; Landraces; Physicochemical traits; Pisum sativum; Rainfed

\section{Introduction}

Pea (Pisum sativum L.) is one of the important winter crop belongs to family leguminosae, grown all over the world for fresh and processed forms. It is originated in the central or South East Asia. Pea is the world's third most significant legume grain after soybean and common beans [1]. Pea is an excellent source of human diet, either eaten as vegetable and soup. Pea is rich source of protein, vitamins $\mathrm{A}, \mathrm{B}$ and $\mathrm{C}$ and 
also contains a high proportion of minerals [2].

In Pakistan, pea is an important crop, which plays a major role in farmer's economy. It is the most common crop and enjoys a great commercial demand due to its nutritive value. It is cultivated during winter in plains and during summer in highlands [2]. In Pakistan, it is cultivated on an area of 10 thousand hectares with a total production of 72 thousand metric tons [3].Average yield per hectare of peas in Pakistan is quite low (7.2 t/ha) as compared to its potential and yield obtained in other countries [4]. Pea with other legumes crops covers an area of approximately 1066 ha of crop areas in Azad Jammu and Kashmir (AJK)-Pakistan and is very vital food legume as compared with pulses grown in this area [5].

As compared to many other countries, the average yield of pea crop is very low in Pakistan which may be attributed due to the non-adoption of improved varieties. Santalla et al. [6] have also reported that variation in old and unimproved varieties needed to determine in order to create valuable genetic variability for expansion of the narrow genetic base of profitable cultivars and for production of effectual use of resources. Cultivars perform different under different agro climatic conditions and various cultivars of same species grown in same environment often have yield differences. Unit yield and quality of crop is complex characteristics depending on organic arrangements between environment and heredity. The characteristics of a cultivar as well as combinations of traits differ according to climatic conditions of localities [7].

Now a day, breeding techniques have progressed fastly as the need for high quality food has increased gradually. The initial step for crop genetic enhancement is the assessment of traditional genetic resources. It is need to imperative manage and save indigenous genetic resources, for the reason that they possibly contain valued alleles for crop enhancement. It is therefore needed to explore indigenous germplasm for physicochemical features and general quality [8].

Keeping all these issues in view, present research work was designed to evaluate the available material for yield and other biochemical traits. Availability of genetic variability is vital for any breeding program which offers chance for choice of desired genotypes. Gupta et al. [9] have also reported about existence of considerable amount of genetic variability in pea. Based on our findings, high yielding disease resistant variety will be recommended for cultivation in the area and in addition to this future hybridization strategies will be designed.

\section{Materials and methods}

Planting material and experimental design Nine pea landraces were collected from different parts of mountainous areas of Azad Jammu and Kashmir-Pakistan. One commonly grown pea cultivars (Meteor) was comprised as control. All pea landraces and cultivar were sown on August 16, 2015, in well-prepared seed beds, using randomized complete block design (RCBD) with three replications. Research was led at the research area of the Department of Horticulture, University of the Poonch, Rawalakot AJKPakistan, which has a natural temperate climate (rainfed conditions). The size of plot was $6 \mathrm{~m}^{2}$ with $15 \mathrm{~cm}$ line to line and $12 \mathrm{~cm}$ plant to plant dispersing with 18 plants in every line. Farm yard manure was applied @ 30 tons per hectare and NPK @ 120-75-50 kg per hectare. NPK was applied during the soil preparation. Nitrogen was applied in form of split doses. Whole plots were treated similar way, and followed by recommended agricultural practices. The material was harvested in December 28, 2015. 


\section{Determination of morphological parameters}

Plant Height $(\mathrm{cm})$, branches per plant, flowers per plant, leaves per plant, seeds per pod, pods per plant, seed weight ( $\mathrm{g} / 100 \mathrm{seed})$, pod length $(\mathrm{cm})$ and total seed yield $(\mathrm{kg} / \mathrm{ha})$ were determined by using standard methods.

Determination of biochemical properties

Total protein content $(\%), \mathrm{pH}$, fiber content $(\%)$, fat content $(\%)$ and carbohydrates $(\mathrm{mg} / \mathrm{g})$ were determined according to standard methods of analysis [10].

\section{Determination of antioxidant activity}

The antioxidative potential from the seeds utilizing the DPPH (1,1-diphenyl-2picrylhydrazyl) radical was estimated. It was performed for half an hour after that adds DPPH (1,1-diphenyl-2-picrylhydrazyl). Measuring little vessel was kept in the darkness at normal temperature. Readings were taken at $517 \mathrm{~nm}$.

All determinations were carried out in triplicate.

\section{Statistical analysis}

Data were subjected to the analysis of variance (ANOVA) and tested for significant differences among treatments by the Least Significant Difference (LSD) test at $(\mathrm{P} \leq$ 0.05) using MSTAT-C software.

\section{Results and discussion \\ Plant height (cm)}

The analysis of variance exhibited that the 9 pea landraces varied significantly from one another with respect to plant height (Table 1). The most extreme plant height $(44.7 \mathrm{~cm})$ of pea was observed in cultivated variety while least plant height was found in Khaigala $(23.4 \mathrm{~cm})$. The plant height was shorter than past studies led at various areas, particularly fall sown plants [11]. The reason of these distinctions can be credited to shorter developing period as an aftereffect of spring sowing. Since pea is a run of the mill cool season plant and its height increase under favorable, cool and moist conditions [12]. Different responses to plant height might be due to genetic characteristic of cultivars and adaptability to a particular environment. The dwarf plant which could not benefit from prevailing climatic condition showed less adaptability in tested area.

\section{Number of branches per plant}

The statistical analysis indicated significant differences among pea's landraces regarding number of branches per plant (Table 1). Paniola accomplished maximum number of branches per plant (8.26) while the minimum numbers of branches were seen in Parat (7.55). More opportunity to blooming in a few genotypes with more number of branches means that more vegetative development because of climatic conditions. It was watched that a few genotypes had determinate sort development and their plant blossomed and depleted at the same time. The germplasm collected from different climatic circumstances, degree of adaptation may be measured the possible cause of difference. This variation could be due to genetic variability of different germplasms. Same results observed by Hussain and Badshah [13].

\section{Number of flowers per plant}

Results revealed that the highest numbers of flowers were seen in variety (5.32) while least quantities of flowers (2.00) were found in Pothi. Pea cultivars have an adequately extensive variety of term of vegetative period and their subsequent stages (blooming, development and so on) [14].

Number of leaves per plant

There was considerable diversity among the landraces for the number of leaves per plant (Table 1). The results exhibited that maximum numbers (32.8) of leaves per plant were noted in Bakh while minimum numbers (31.53) of leaves per plant were seen in Jandali. This variation could be due to genetic variability of diverse germplasms [13]. 


\section{Number of seeds per pod}

Maximum values for this parameter was recorded in variety (6.83). Range of minimum value was (3.13). The quantities of seeds per pod depend mostly on the species also on the natural environment. Numbers of seeds are correlated with pod length. Maximum pod length results in maximum number of seeds. The possible reason of less number of seeds per pod may be that environment was not suitable at the time of pollination and fertilization. Cool climate with moderate rainfall at the time of pollination and fertilization produced more number of seeds per pod as compared to dry climate and heavy rainfall at these stages [15].

\section{Number of pods per plant}

Greatest number of pods per plant were found in $(10.2 \mathrm{~cm})$ in variety, while minimum were observed in Trar $(4.00 \mathrm{~cm})$. Pods per plant decreased sharply because of warm climate during germination stage. Pea is sensitive to high temperature particularly during germination stage. More number of pods per plant may be due to small pod size as less nutrient are required for small pods compared with larger pods. Number of pods per plant relate to plant height. Vigorous varieties produced more pods while number of pods decreased with decrease in plant height, which might be attributed to genetic makeup of the plants. Pods per plant have significant and positive correlation with biological yield, grain yield and harvest index. Similar results have also been reported earlier. Some researchers observed number of pods per plant as the most useful yield component [4].

\section{Seed weight}

Maximum number of hundred seed weight was found in Bakh (23.93) while minimum weight was found in Trar (22.83). Average seed weight was inversely correlated with seed yield. Ayaz et al. [16] showed decrease in average seed weight of pea's cultivars with increased plant population. Strong association between source and sink and maximum translocation of food material from vegetative portion to reproductive phase in good environmental circumstance which cause greater seed weight.

\section{Pod length $(\mathbf{c m})$}

Information on pod length indicated huge contrasts among the genotypes. A correlation of means for cultivars demonstrated that Paniola displayed the maximum pod length $(8.16 \mathrm{~cm})$ while minimum pod length $(4.50$ $\mathrm{cm})$ was recorded in variety. Pea cultivars vary greatly in size and shape and number of seeds per pod. Pod size is a varietal character, but it is also affected by vigor of plant. Greater availability of nutrients especially during pod formation and development stages of more vigorous pea varieties might have translocated maximum of its reserved food material towards pod formation and development [17].

\section{Total seed yield (kg/ha)}

Information figured on seed yield was regarded to measurable examination and analysis is shown in (Table 1). In (Table 1) showed that maximum yields were found in variety $(12.957 \mathrm{~kg} / \mathrm{ha})$, while minimum were presented in Bakh $(8.300 \mathrm{~kg} / \mathrm{ha})$. Hotter climate condition and hail cases must be in charge of diminishing seed yield execution since high temperature during blossoming and pod arrangement cause diminish in seed yield in pea [18]. Different cultivars differed in their yield capability optimum temperature and relative humidity during grain filling period might also be responsible for maximum translocation of photo assimilates towards final end product. Positive association of grain yield with plant height, pods per plant and stem girth has also been observed under field or rainfed conditions.

\section{Proximate composition}

Based on preliminary ANOVA study (data not shown), 9 field pea landraces varied significantly in all studied proximate composition traits such as protein content, 
$\mathrm{pH}$, fiber content, fat content and carbohydrates. Previous research has also revealed significant differences in the proximate configurations of different pea genotypes from various geographic regions of the world [19]. There was positive variation in protein content of pea landraces, with the highest protein levels seen in Bakh $(20.23 \%)$ and the lowest $(10.76 \%)$ in Dreak (Table 2). Maximum $\mathrm{pH}$ was found in variety (7.8) while minimum was observed in Parat (5.0). This variation could be due to genetic variability of different germplasms. The fiber content ranged from (0.76-7.20\%). Variety had the highest fiber content and Khaigala the lowest. Similar results were reported by Kumar [20]. Maximum fat was perceived in Jandali $(2.860 \%)$ while minimum was found in Pothi (1.200\%). Similar results were reported by Nikolopoulou et al. [21]. There was huge contrast among treatments for carbohydrates. Comes about showing huge distinction for treatments are given in (Table 2) for examination to their means. It is obvious from the table 2 that maximum carbohydrates were found in Pothi (94.38\%) while the minimum $(79.1 \%)$ was obtained in variety. Similar results were reported by [20]. Antioxidant activity (\%)

Significant difference among treatments for antioxidant activity results exhibiting significant difference for treatments were subjected to LSD test and are given in (Table 2) for their means. Mean values of antioxidant activity revealed that higher values were recorded in Paniola (4.63\%) and least value of antioxidant activity was $(3.83 \%)$ in variety. The antioxidant is mainly scavengers that reduce various free radicals and serving in avoidance of cellular injury and other injury. Pea's antioxidant has ability to produce resistance in tissues against diseases and stress conditions. A lot of antifungal molecules may encourage postharvest disease resistance such as phenolic compounds which take part in a binary role by acting as antifungal agents to enhance postharvest life and also as antioxidant to recover the quality during conservation of food products [22].

\section{Correlation among trait}

The relationships amongst the numerous traits are represented in (Table 3). Seed per plant was negatively correlated with branches per plant. Seed weight was negatively correlated with height of the plant. Pod length was significantly positively correlated with plant height and seed weight. Seed yield was positively correlated with seed weight, but negatively with pod length. $\mathrm{pH}$ was significantly positively associated height and pod length, however negatively with seed weight and seed yield. In the meantime, protein content was positively correlated with pod length and $\mathrm{pH}$, however negatively correlated with seed weight and seed yield. Meanwhile, fiber content was significantly correlated with pod length and protein content, but negatively with seed yield. Fat content was significantly correlated with flowers per plant. As for carbohydrate content was significantly associated with seed weight and seed yield and negative correlation was seem with height, pod length, $\mathrm{pH}$, protein and fiber content. Antioxidants were significantly positively correlation with height, pod length, $\mathrm{pH}$, protein and fiber content, but negatively with seed weight, seed yield and carbohydrate content.

Relationships between traits can flow from genetic linkage or pleiotropic consequence, but the environment can also play a great role. These environmental effects can impulsion a pair of traits whichever in the similar or in conflicting way [23]. Therefore, at this phase, the associations we have stated must be realized as initial phase, till multilocation evaluation can display the comparative aids of environment and genes. 
Table 1. Morphological characteristics of field pea landraces and cultivar (Meteor) $\left(^{\dagger}\right)$

\begin{tabular}{|c|c|c|c|c|c|c|c|c|c|}
\hline Landraces & $\begin{array}{c}\text { Plant } \\
\text { Height }(\mathbf{c m})\end{array}$ & $\begin{array}{l}\text { Branches } \\
\text { per plant }\end{array}$ & $\begin{array}{c}\text { Flowers } \\
\text { per plant }\end{array}$ & $\begin{array}{l}\text { Leaves per } \\
\text { plant }\end{array}$ & $\begin{array}{l}\text { Seeds per } \\
\text { pod }\end{array}$ & $\begin{array}{c}\text { Pods per } \\
\text { plant }\end{array}$ & $\begin{array}{l}\text { Seed weight } \\
\text { (g/100 seed) }\end{array}$ & $\begin{array}{c}\text { Pod } \\
\text { length }(\mathrm{cm})\end{array}$ & $\begin{array}{c}\text { Total Seed } \\
\text { yield (kg/ha) }\end{array}$ \\
\hline Paniola & $30.3 \mathrm{~b}$ & $9.05 \mathrm{a}$ & $2.66 \mathrm{~b}$ & $31.93 \mathrm{~b}$ & $3.13 \mathrm{c}$ & $5.00 \mathrm{~b}$ & $23.16 \mathrm{~b}$ & $8.16 \mathrm{a}$ & $10.633 \mathrm{~b}$ \\
\hline Bakh & $27.6 \mathrm{~b}$ & $8.26 \mathrm{~b}$ & $3.30 \mathrm{~b}$ & $32.80 \mathrm{a}$ & $4.63 \mathrm{~b}$ & $5.33 \mathrm{~b}$ & $23.93 \mathrm{a}$ & $4.83 \mathrm{~b}$ & $8.300 \mathrm{c}$ \\
\hline Dreak & $30.5 \mathrm{~b}$ & $8.00 \mathrm{~b}$ & $3.51 \mathrm{~b}$ & $31.93 \mathrm{~b}$ & $4.67 \mathrm{~b}$ & $4.66 \mathrm{~b}$ & $22.80 \mathrm{c}$ & $6.00 \mathrm{~b}$ & $10.867 \mathrm{~b}$ \\
\hline Jandali & $32.0 \mathrm{~b}$ & $7.90 \mathrm{~b}$ & $4.00 \mathrm{~b}$ & $31.53 \mathrm{c}$ & $3.34 \mathrm{~b}$ & $4.33 \mathrm{~b}$ & $23.30 \mathrm{~b}$ & $4.66 \mathrm{~b}$ & $10.300 \mathrm{~b}$ \\
\hline Khaigala & $23.4 \mathrm{c}$ & $7.73 \mathrm{~b}$ & $2.05 \mathrm{~b}$ & $31.90 \mathrm{~b}$ & $4.21 \mathrm{~b}$ & $4.01 \mathrm{~b}$ & $23.40 \mathrm{~b}$ & $6.00 \mathrm{~b}$ & $11.967 \mathrm{~b}$ \\
\hline Khrick & $23.6 \mathrm{~b}$ & $7.70 \mathrm{~b}$ & $2.30 \mathrm{~b}$ & $32.53 \mathrm{~b}$ & $4.39 \mathrm{~b}$ & $6.67 \mathrm{~b}$ & $23.46 \mathrm{~b}$ & $4.52 \mathrm{~b}$ & $9.433 \mathrm{~b}$ \\
\hline Pothi & $25.0 \mathrm{~b}$ & $7.61 \mathrm{~b}$ & $2.00 \mathrm{c}$ & $32.57 \mathrm{~b}$ & $4.81 \mathrm{~b}$ & $4.61 \mathrm{~b}$ & $23.79 \mathrm{~b}$ & $4.79 \mathrm{~b}$ & $9.992 \mathrm{~b}$ \\
\hline Trar & $35.2 \mathrm{~b}$ & $7.56 \mathrm{~b}$ & $2.10 \mathrm{~b}$ & $32.00 \mathrm{~b}$ & $4.33 \mathrm{~b}$ & $4.00 \mathrm{c}$ & $22.83 \mathrm{~b}$ & $5.66 \mathrm{~b}$ & $9.433 \mathrm{~b}$ \\
\hline Parat & $30.9 \mathrm{~b}$ & $7.55 \mathrm{c}$ & $3.94 \mathrm{~b}$ & $31.90 \mathrm{~b}$ & $5.41 \mathrm{~b}$ & $4.67 \mathrm{~b}$ & $23.76 \mathrm{~b}$ & $5.33 \mathrm{~b}$ & $8.533 \mathrm{~b}$ \\
\hline Meteor & $44.7 \mathrm{a}$ & $8.05 \mathrm{~b}$ & $5.32 \mathrm{a}$ & $32.14 \mathrm{~b}$ & $6.83 \mathrm{a}$ & $10.2 \mathrm{a}$ & $23.56 \mathrm{~b}$ & $4.50 \mathrm{c}$ & $12.957 \mathrm{a}$ \\
\hline Range & 23.4-44.7 & 7.55-9.05 & $2-5.32$ & 31.53-32.80 & $3.13-6.83$ & $10.2-6.67$ & $22.80-23.93$ & 4.50-8.16 & $10.30-9.99$ \\
\hline LSD & 5.217 & 2.110 & 5.217 & 2.110 & 2.110 & 2.110 & 2.110 & 2.110 & 5.217 \\
\hline
\end{tabular}

"Means with different letters in column are significantly different at $P<0.05$ using LSD. Each value is the mean of three replicates 
Table 2. Biochemical analysis of field pea landraces and cultivar (Meteor) $\left({ }^{\dagger}\right)$

\begin{tabular}{|c|c|c|c|c|c|c|}
\hline Landraces & $\mathbf{p H}$ & $\begin{array}{l}\text { Total protein } \\
\text { content }(\%)\end{array}$ & $\begin{array}{c}\text { Fiber content } \\
(\%)\end{array}$ & Fat content $(\%)$ & $\begin{array}{c}\text { Carbohydrates } \\
(\%)\end{array}$ & $\begin{array}{l}\text { Antioxidant } \\
\text { activity (\%) }\end{array}$ \\
\hline Paniola & $7.5 \mathrm{~b}$ & $20.00 \mathrm{~b}$ & $0.83 \mathrm{~b}$ & $1.700 \mathrm{~b}$ & $89.73 \mathrm{~b}$ & $4.63 \mathrm{a}$ \\
\hline Bakh & $7.6 \mathrm{a}$ & $20.23 \mathrm{a}$ & $1.26 \mathrm{~b}$ & $1.300 \mathrm{~b}$ & $88.42 \mathrm{~b}$ & $4.13 \mathrm{~b}$ \\
\hline Dreak & $7.0 \mathrm{~b}$ & $10.76 \mathrm{~b}$ & $1.33 \mathrm{~b}$ & $1.126 \mathrm{~b}$ & $90.15 \mathrm{~b}$ & $4.43 \mathrm{~b}$ \\
\hline Jandali & $6.4 \mathrm{~b}$ & $20.04 \mathrm{~b}$ & $1.40 \mathrm{~b}$ & $2.860 \mathrm{a}$ & $86.56 \mathrm{~b}$ & $4.13 \mathrm{~b}$ \\
\hline Khaigala & $6.3 \mathrm{~b}$ & $20.20 \mathrm{~b}$ & $0.76 \mathrm{c}$ & $1.473 \mathrm{~b}$ & $88.32 \mathrm{~b}$ & $4.63 \mathrm{a}$ \\
\hline Khrick & $6.4 \mathrm{~b}$ & $20.10 \mathrm{~b}$ & $1.93 \mathrm{~b}$ & $1.713 \mathrm{~b}$ & $85.88 \mathrm{~b}$ & $4.06 \mathrm{~b}$ \\
\hline Pothi & $5.7 \mathrm{~b}$ & $20.20 \mathrm{a}$ & $1.15 \mathrm{~b}$ & $1.200 \mathrm{c}$ & $94.38 \mathrm{a}$ & $4.60 \mathrm{~b}$ \\
\hline Trar & $5.4 \mathrm{~b}$ & $20.00 \mathrm{~b}$ & $0.83 \mathrm{~b}$ & $1.446 \mathrm{~b}$ & $89.73 \mathrm{~b}$ & $4.50 \mathrm{~b}$ \\
\hline Parat & $5.0 \mathrm{c}$ & $10.93 \mathrm{c}$ & $2.21 \mathrm{~b}$ & $1.300 \mathrm{~b}$ & $90.96 \mathrm{~b}$ & $4.46 \mathrm{~b}$ \\
\hline Meteor & $7.8 \mathrm{a}$ & $20.06 \mathrm{~b}$ & $7.20 \mathrm{a}$ & $2.733 \mathrm{~b}$ & $79.10 \mathrm{c}$ & $3.83 \mathrm{c}$ \\
\hline Range & $5.0-7.8$ & $10.76-20.23$ & $0.76-7.20$ & $1.12-2.86$ & 79.1-94.38 & $3.83-4.63$ \\
\hline LSD & 5.137 & 5.137 & 5.137 & 2.093 & 5.137 & 2.09 \\
\hline
\end{tabular}

"Means with different letters in column are significantly different at $P<0.05$ using LSD. Each value is the mean of three replicates 
Bashir et al.

Table 3. Trait correlations among physicochemical properties of field pea landraces and cultivar (Meteor).

\begin{tabular}{|c|c|c|c|c|c|c|c|c|c|c|c|c|c|c|}
\hline & Height & $\begin{array}{l}\text { Branch } \\
\text { es } \\
\text { plant }^{-1}\end{array}$ & $\begin{array}{c}\text { Flow } \\
\text { ers } \\
\text { plant } \\
-1\end{array}$ & $\begin{array}{l}\text { Leaves } \\
\text { plant }^{-1}\end{array}$ & $\begin{array}{c}\text { Seed } \\
\text { S } \\
\text { plant } \\
-1\end{array}$ & $\begin{array}{c}\text { Pods } \\
\text { plant } \\
-1\end{array}$ & $\begin{array}{c}\text { Seed } \\
\text { weight }\end{array}$ & $\begin{array}{l}\text { Pod } \\
\text { length }\end{array}$ & $\begin{array}{l}\text { Seed } \\
\text { yield }\end{array}$ & pH & $\begin{array}{c}\text { Prote } \\
\text { in }\end{array}$ & Fiber & Fat & $\begin{array}{c}\text { Carbohy } \\
\text { drates }\end{array}$ \\
\hline Branches plant $^{-1}$ & 0.395 & & & & & & & & & & & & & \\
\hline Flowers plant $^{-1}$ & 0.116 & 0.382 & & & & & & & & & & & & \\
\hline Leaves plant $^{-1}$ & 0.069 & -0.032 & $\begin{array}{c}- \\
0.384 \\
\end{array}$ & & & & & & & & & & & \\
\hline Seeds plant ${ }^{-1}$ & 0.304 & $-0.667 *$ & 0.066 & 0.421 & & & & & & & & & & \\
\hline Pods plant $^{-1}$ & 0.148 & 0.138 & 0.409 & 0.403 & 0.431 & & & & & & & & & \\
\hline Seed weight & $-0.658^{*}$ & 0.331 & 0.320 & 0.176 & 0.354 & 0.269 & & & & & & & & \\
\hline Pod Length & $0.622 *$ & -0.334 & 0.103 & -0.288 & 0.488 & $\begin{array}{c}- \\
0.277 \\
\end{array}$ & $\begin{array}{c}0.985^{*} \\
*\end{array}$ & & & & & & & \\
\hline Seed yield & -0.536 & 0.373 & $\begin{array}{c}- \\
0.190 \\
\end{array}$ & -0.096 & $\begin{array}{c}- \\
0.612 \\
\end{array}$ & $\begin{array}{c}- \\
0.045 \\
\end{array}$ & $\begin{array}{c}0.814 * \\
*\end{array}$ & $\begin{array}{c}- \\
0.862 * * \\
\end{array}$ & & & & & & \\
\hline pH & $0.743 *$ & -0.002 & 0.163 & 0.337 & 0.258 & $\begin{array}{c}- \\
0.140\end{array}$ & $\begin{array}{c}0.837 * \\
*\end{array}$ & $0.865 * *$ & $0 . \overline{819}$ ** & & & & & \\
\hline Protein & 0.567 & -0.461 & 0.018 & -0.177 & 0.592 & $0 . \overline{249}$ & $\begin{array}{c}-\overline{-} \\
0.984 \\
*\end{array}$ & $0.974 * *$ & $0.905^{* *}$ & $\begin{array}{c}0.836 \\
* *\end{array}$ & & & & \\
\hline Fiber & 0.381 & -0.572 & 0.182 & 0.054 & 0.506 & 0.346 & -0.595 & $0.610^{*}$ & ${ }^{-}{ }^{-}-792^{* *}$ & 0.530 & $\begin{array}{c}0.674 \\
*\end{array}$ & & & \\
\hline Fat & 0.085 & 0.052 & $\begin{array}{c}0.639 \\
*\end{array}$ & -0.501 & $\begin{array}{c}- \\
0.361 \\
\end{array}$ & 0.001 & 0.450 & -0.076 & 0.064 & $\begin{array}{c}- \\
0.218\end{array}$ & $\begin{array}{c}- \\
0.116 \\
\end{array}$ & 0.052 & & \\
\hline Carbohydrates & $-0.064 *$ & 0.118 & -1.20 & 0.250 & $\begin{array}{c}- \\
0.550\end{array}$ & 0.279 & $\begin{array}{c}0.996 * \\
*\end{array}$ & $0.986^{-}$ & $0.902 * *$ & $\begin{array}{c}- \\
0.850 \\
* *\end{array}$ & $\begin{array}{c}- \\
0.990 \\
* *\end{array}$ & $-0.706^{*}$ & 0.044 & \\
\hline Antioxidants & $0.600 *$ & -0.440 & .103 & -0.237 & 0.577 & $\begin{array}{c}- \\
0.252 \\
\end{array}$ & $\begin{array}{c}- \\
0.999 * \\
\end{array}$ & $0.990 * *$ & $\begin{array}{c}- \\
0.899 * *\end{array}$ & $\begin{array}{c}0.842 \\
* *\end{array}$ & $\begin{array}{c}0.991 \\
* *\end{array}$ & $0.684^{*}$ & -0.072 & $-0.998 * *$ \\
\hline
\end{tabular}

$*$ Correlation is significant at 0.05 level; **Correlation is significant at 0.01 level 


\section{Conclusion and recommendations}

Nine field pea genotypes/landraces were explored from different location of District Poonch of Azad Jammu and Kashmir (Pakistan). Physicochemical analysis showed significant variances among the genotypes for their nutritional composition. Some accessions collected from Paniola had excellent nutritional value. There were positive relationships amongst the traits investigated, signifying that assortment for one trait indirectly designated for other trait(s). The evidence providing in the current research is first significant phase for field pea breeding programs. Genetic diversity found in can be exploited for improvement of existing cultivars and promising genotypes/landraces can be popularized and planted on commercial scale. Further multilocation trials are needed to assess the various landraces of field pea.

\section{Authors' contributions}

Conceived and designed the experiments: SZA Shah \& A Hamid, Performed the experiments: S Bashir, A Yaqoob \& ZH Khan, Analyzed the data: N Zahid \& A Afzal, Contributed reagents/materials/analysis tools: SZA Shah \& MI Khan, Wrote the paper: RMM Naz, S Anjum \& M Maqbool.

\section{References}

1. Timmerman-Vaughan GM, Mills A, Whitfield C, Frew T, Butler R, Murray S \& Wilson D (2005). Linkage mapping of QTL for seed yield, yield components, and developmental traits in pea. Crop Sci 45: 1336-1344.

2. Habib N \& Zamin M (2003). Off-season pea cultivation in Dir Kohistan valley. Asian J Plant Sci 2: 283-285.

3. Anonymous (1999). FAO Production Year Book. FAO, Rome, Italy.

4. Amjad M \& Anjum MA (2002). Performance of nine pea cultivars under Faisalabad conditions. Pak J Agric Sci 39: 6-19.

5. Government of Azad Jammu and Kashmir (2009). Azad Kashmir at a glance. Department of planning and development, Muzaffarabad, Pakistan.

6. Santalla M, Amurrio JM \& De Ron AM (2001). Food and feed potential breeding value of green, dry and vegetable pea germplasm. Can J Plant Sci 81: 601610.

7. Kakar AA, Saleem M, Shah R \& Shah SQ (2002). Growth and marketable green pod yield performance of pea (Pisum sativum L.) under varying levels of NPK fertilizers. Asian J Plant Sci 1: 532-534.

8. Özer S, Karaköy T, Toklu F, Baloch FS, Kilian B \& Özkan H (2010). Nutritional and physicochemical variation in Turkish kabuli chickpea (Cicer arietinum L.) landraces. Euphytica 175: 237-249.

9. Gupta AJ, Singh YV \& Verma TS (2006). Genetic variability and heritability in garden pea (Pisum sativum L.). Indian J Horti 63: 332-334.

10. A.O.A.C. (1995). Official method of analysis. The association of official analytical chemist. $16^{\text {th }} \quad$ Edition. Arlington, USA.

11. Uzun A, Bilgili U, Sincik M, Filya I \& Acikgoz E (2005). Yield and quality of forage type pea lines of contrasting leaf types. Eur J Agronomy 22: 85-94.

12. Murray GA \& Swensen JB (1985). Seed Yield of Austrian Winter Field Peas Intercropped with Winter Cereals L. Agronomy J 77: 913-916.

13. Hussain SA \& Badshah N (2002). Study on the adaptive behaviour of exotic pea (Pisum sativum L.) varieties under local conditions of Peshawar. Asian J Plant Sci 1: 567-569.

14. Makasheva RK (1983). The Pea (Pisum sativum L.). Oxonian Press Private Limited New Delhi India, 267-271.

15. Cousin R (1997). Peas (Pisum sativum L.). Field Crops Res 53(1-3): 111-130. 
16. Ayaz S, McKenzie BA, Hill GD \& McNeil DL (2004). Variability in yield of four grain legume species in a subhumid temperate environment. II. Yield components. J Agric Sci 142: 2128.

17. Muehlbauer FJ, Redden RJ, Nassib AM, Robertson LD, \& Smithson JB (1988). Population improvement in pulse crops: an assessment of methods and techniques. In World crops: Cool season food legumes (pp 943-966). Springer, Dordrecht.

18. Acikgoz E, Ustun A, Gul I, Anlarsal E, Tekeli AS, Nizam I \& Yucel C (2009). Genotype $\mathrm{x}$ environment interaction and stability analysis for dry matter and seed yield in field pea (Pisum sativum L.). Span J Agric Res 7: 96-106.

19. Özer S, Tümer E, Baloch FS, Karaköy T, Toklu F \& Özkan H (2012). Variation for nutritional and cooking properties among Turkish field pea landraces. $J$ Food Agric Environ 10: 324-329.
20. Kumar N (2015). Green pea pods spoilage due to Fusarium oxysporum Schltdl. at Panchgaon, Gurgaon, Haryana, India. Int J Curr Microbiol App Sci 4: 426-431.

21. Nikolopoulou D, Grigorakis K, Stasini M, Alexis MN \& Iliadis K (2007). Differences in chemical composition of field pea (Pisum sativum) cultivars: effects of cultivation area and year. Food Chem 103: 847-852.

22. Chahbani A, Fakhfakh N, Balti MA, Mabrouk M, El-Hatmi H, Zouari N, \& Kechaou N (2018). Microwave drying effects on drying kinetics, bioactive compounds and antioxidant activity of green peas (Pisum sativum L.). Food Biosci 25: 32-38.

23. Yücel C, Baloch FS \& Özkan H (2009). Genetic analysis of some physical properties of bread wheat grain (Triticum aestivum L. em Thell). Turk J Agric For 33: 525-535. 